Canadian Journal of Higher Education

Revue canadienne d'enseignement supérieur

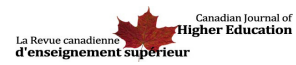

\title{
Levels of Psychological Distress of Canadian University Student-Athletes
}

\author{
Philip Sullivan, Mishka Blacker, Jessica Murphy and John Cairney
}

Volume 49, Number 1, 2019

URI: https://id.erudit.org/iderudit/1060823ar

DOI: https://doi.org/10.7202/1060823ar

\section{See table of contents}

Publisher(s)

Canadian Society for the Study of Higher Education

ISSN

2293-6602 (digital)

Explore this journal

Cite this article

Sullivan, P., Blacker, M., Murphy, J. \& Cairney, J. (2019). Levels of Psychological Distress of Canadian University Student-Athletes. Canadian Journal of Higher Education / Revue canadienne d'enseignement supérieur, 49(1), 47-59.

https://doi.org/10.7202/1060823ar
Article abstract

The mental health of Canadian university students is fairly well researched, but there is relatively little evidence concerning the mental health of Canadian university student-athletes. Recent research in the United States and Canada has suggested that mental health (e.g., anxiety and depression) differs between student-athletes and student non-athletes. However, the results are ambivalent as to whether student-athletes experience more or less psychological distress than their non-athlete peers. To address this gap, the purpose of the current study was to measure the levels of psychological distress in a national sample of 284 university student-athletes. Each athlete completed the Kessler Psychological Distress Scale (K6; Kessler et al., 2002) via a secure online platform. The average score on the K6 for student-athletes was 8.2 out of 24; $19.8 \%$ of the sample surpassed the cut-off for assessing the prevalence of severe mental illness. A regression analysis found that gender, starting status, and scholarship status significantly predicted levels of psychological distress. Females, non-starters, and student-athletes without a scholarship were associated with increases in K6 scores.
Copyright (c) Philip Sullivan, Mishka Blacker, Jessica Murphy, John Cairney, 2019
This document is protected by copyright law. Use of the services of Érudit (including reproduction) is subject to its terms and conditions, which can be viewed online.

https://apropos.erudit.org/en/users/policy-on-use/ 
Canadian Journal of Higher Education Revue canadienne d'enseignement supérieur

Volume 49, No. 1, 2019, pages 47 - 59

\title{
Levels of Psychological Distress of Canadian University Student-Athletes
}

\author{
Philip Sullivan, Mishka Blacker, \& Jessica Murphy \\ Brock University
}

\begin{abstract}
The mental health of Canadian university students is fairly well researched, but there is relatively little evidence concerning the mental health of Canadian university student-athletes. Recent research in the United States and Canada has suggested that mental health (e.g., anxiety and depression) differs between student-athletes and student non-athletes. However, the results are ambivalent as to whether student-athletes experience more or less psychological distress than their non-athlete peers. To address this gap, the purpose of the current study was to measure the levels of psychological distress in a national sample of 284 university student-athletes. Each athlete completed the Kessler Psychological Distress Scale (K6; Kessler et al., 2002) via a secure online platform. The average score on the K6 for student-athletes was 8.2 out of $24 ; 19.8 \%$ of the sample surpassed the cut-off for assessing the prevalence of severe mental illness. A regression analysis found that gender, starting status, and scholarship status significantly predicted levels of psychological distress. Females, non-starters, and student-athletes without a scholarship were associated with increases in K6 scores.
\end{abstract}

\section{Résumé}

La santé mentale des étudiants postsecondaires canadiens fait l'objet de beaucoup de recherches, mais il existe relativement peu de preuves entourant la santé mentale des étudiants-athlètes postsecondaires canadiens. La recherche récente aux États-Unis et au Canada suggère que la santé mentale (par exemple, l'anxiété et la dépression) varie entre étudiants-athlètes et 
non-athlète étudiants. Cependant, les résultats sont ambivalents à savoir si les étudiants-athlètes éprouvent plus ou moins de détresse mentale que les pairs non-athlètes. Pour combler cette lacune dans la recherche, la présente étude vise à déterminer les niveaux de détresse mentale dans un échantillon pancanadien de 284 étudiants-athlètes postsecondaires. Chaque athlète a été évalué selon le Kessler Psychological Distress Scale (K6; Kessler et al., 2002) par l'entremise d'une plateforme en ligne sécurisée. Le résultat moyen chez le K6 pour les étudiants-athlètes était de 8,2 sur 24; 19,8\% de l'échantillon a dépassé le seuil d'évaluation de la prévalence de la maladie mentale grave. Une analyse de régression a révélé que le sexe, le fait d'être de ceux qui commencent le match, de même que le statut de boursier, prédisent de manière significative les niveaux de détresse mentale. Les femmes, ceux qui ne commencent pas le match, et les étudiants-athlètes sans bourse ont obtenu des scores K6 plus élevés.

\section{Introduction}

Research into the mental health and distress of university students shows consistent, alarming findings (Hunt \& Eisenberg, 2010; Stallman, 2010). The 2009 summary by the Ontario College Health Association (OCHA) of the mental health of Canadian university and college students reported that students are more than twice as likely to report psychological distress than non-students. A Canadian survey conducted in 2016 found that 46.1\% of Canadian students felt "so depressed that it was difficult to function," and 65.4\% of respondents felt "overwhelming anxiety" within the last 12 months (American College Health Association, 2016).

While research has identified that post-secondary students are at a higher risk of mental illness compared to non-students, additional factors influencing mental health have also been found. One of the most widely cited factors in both the general population and the university setting is gender, with females consistently displaying higher prevalence of depression, anxiety, and psychological distress as compared to males (Eisenberg, Golberstein, \& Gollust, 2007; Hunt \& Eisenberg, 2010; Mori, 2000; Stallman, 2010). A survey of 1,000 Canadian students found a significant gender difference on a global measure of mental health, with females scoring significantly higher than males on each of the 12 composite items (e.g., constantly under strain, been unhappy or depressed, lost sleep over worry). In addition to impacting the prevalence of mental health disorders, gender has also been shown to effect age of onset, frequency of symptoms, ability to adjust, and overall outcome (World Health Organization, 2018). Immigration status (Mori, 2000), grade point average, year of study (Stallman, 2010), and academic involvement (Adlaf, Gliksman, Demers, \& Newton-Taylor, 2001) have also been found to be related to university students' mental health.

\section{Literature Review}

The mental health of university students is a significant social concern, and specific subgroups within this population warrant individual attention. One of these subpopulations is student-athletes, a significant and highly visible population, who preliminary 
research suggests may experience different levels of mental health compared to student non-athletes. Student-athletes are a unique group of students, representing over 12,000 registered athletes (USports, 2017), and many others participating at regional levels (e.g., Ontario University Athletics or Atlantic University Sport). Because of their dual-role situation, student-athletes have a significantly different university experience than their nonathlete counterparts, including different stressors and resources that may affect rates of mental health disorders (Davoren \& Hwang, 2014; Miller \& Hoffman, 2009; Wolanin, Hong, Marks, Panchoo, \& Gross, 2016). Noted stressors of student-athletes identified in an American study included academic anxiety, demanding or negative coaching behaviours, injury risk, and sleep quality (Davoren \& Hwang, 2014). Despite these identified stressors, results from this same study found that student-athlete status was a significant negative predictor for anxiety and depression. These results were consistent across genders with both male and female athletes reporting lower prevalence of anxiety and depression as compared to their same-sex, non-athlete peers (Davoren \& Hwang, 2014). These results could be explained by evidence from Kimball and Freysinger (2003), that sport itself may act as a buffer against stress and that student-athletes have access to coaching and training staff who they perceive as potential resources for their mental health (Lopez \& Levy, 2013; Moulton, Molstad, \& Turner, 1997). Although the above statistics on student-athlete mental health are encouraging, these results were collected from American varsity athletes, and there are substantial differences between the Canadian and American collegiate sporting systems that cannot be ignored.

In Canada, the potential differences between students in general and student-athletes with respect to mental health are significantly under-researched. For example, student-athletes in Canadian universities typically play in front of much smaller crowds than their American counterparts, their competitions are rarely televised, and media attention is less prevalent in the Canadian than the American system (Miller \& Kerr, 2002). While American student-athletes may receive "full scholarships" that cover tuition, fees, and living expenses (National Collegiate Athletic Association [NCAA], n.d.), athletic scholarships in Canada tend to be much smaller. For example, Ontario University Athletics (n.d.) limits athletic scholarships to a maximum of $\$ 4,500$ per year. In addition to these differences, disparities in the education and health care systems between the United States and Canada are substantial enough to temper any attempts to generalize the NCAA task force's conclusions to a Canadian population.

\section{The Current Study}

Recent work around student mental health has added valuable knowledge regarding the prevalence of depression, anxiety, and psychological distress. However, very few Canadian studies have focused on the mental health of varsity athletes. Due to the differences between Canadian and American school systems and athletic associations, it is impossible to generalize information from the United States to a Canadian population. This study was designed to address this gap in the literature by assessing the levels of psychological distress experienced by a broad and heterogeneous sample of Canadian university student-athletes. Given the current state of the field, this study was considered exploratory and no specific hypotheses were put forward. 


\section{Methods}

\section{Participants}

The 284 participants represented all years of study (first to fifth) and played over 10 sports. Participants were both male and female, ranging in age from 17 to 30 years $(M=$ 20.33, $S D=1.95$ ); the majority were Caucasian (98.6\%). Respondents were from eight of 10 Canadian provinces with Alberta $(n=105)$ and Ontario $(n=114)$ being most represented. With respect to injury status/history, $19.1 \%$ reported being currently injured, and while only $1 \%$ reported being currently concussed, $47.2 \%$ reported having been diagnosed with at least one concussion. Table 1 summarizes the relevant demographic information from the sample.

Table 1. Demographic Information of Sample

\begin{tabular}{|c|c|c|}
\hline \multicolumn{2}{|l|}{ Demographic Variable } & \multirow{2}{*}{$\frac{n}{109}$} \\
\hline Gender & Male & \\
\hline & Female & 179 \\
\hline \multirow[t]{5}{*}{ Year of Study } & First & 68 \\
\hline & Second & 67 \\
\hline & Third & 54 \\
\hline & Fourth & 49 \\
\hline & Fifth & 46 \\
\hline \multirow[t]{4}{*}{ Season Status } & In-Season & 140 \\
\hline & Off-Season & 97 \\
\hline & Playoffs & 4 \\
\hline & Pre-Season & 43 \\
\hline \multirow[t]{2}{*}{ Playing Status } & Starter & 159 \\
\hline & Non-Starter & 125 \\
\hline \multirow[t]{2}{*}{ Athletic Scholarship } & Yes & 143 \\
\hline & No & 141 \\
\hline \multirow[t]{11}{*}{ Sport } & Hockey & 53 \\
\hline & Soccer & 40 \\
\hline & Track and Field & 39 \\
\hline & Rugby & 36 \\
\hline & Basketball & 26 \\
\hline & Swimming & 24 \\
\hline & Volleyball & 20 \\
\hline & Football & 14 \\
\hline & Rowing & 8 \\
\hline & Fencing & 7 \\
\hline & Other & 17 \\
\hline
\end{tabular}




\section{Procedures}

Participants were solicited to participate in the study through the social media platforms of campus student-athlete mental health chapters. Instructions directed studentathletes to an online survey package that included a demographic questionnaire and the psychological distress questionnaire. The online survey included a statement that a completed survey would be interpreted as informed consent. In total, 284 varsity student-athletes completed the study. Unfortunately, due to the nature of recruitment and the inability to assume that all student-athletes follow the social media platform, it was not possible to determine the total number of student-athletes "invited" for this study. As such a rate of participation could not be calculated. However, 93\% of all individuals who began the online data collection form completed it, and all those who completed the form reported being current varsity athletes. Only fully completed survey packages were used in data collection. Participants were not reimbursed in any way for participating in the study.

\section{Measures}

Participants completed a short demographic questionnaire and the Kessler Psychological Distress Scale (K6; Kessler et al., 2002). The K6 is a brief six-item self-report measure to assess non-specific references to psychological distress. Questions ask respondents "during the past 30 days, how often did you feel" (1) nervous; (2) hopeless; (3) restless or fidgety; (4) so depressed that nothing could cheer you up; (5) that everything was an effort; and (6) worthless. Each item is measured on a 0 to 4 scale with higher scores indicating greater frequency of symptoms. The $\mathrm{K} 6$ score is calculated by summing the six items; therefore, the final score of the K6 can range from o to 24. The Cronbach's alpha for the current sample was $\alpha=.865$, indicating an acceptable amount of internal consistency. The K6 has been supported in terms of criterion validity (Cairney, Veldhuizen, Wade, Kurdyak, \& Streiner, 2007; Furukawa, Kessler, Slade, \& Andrews, 2003; Prochaska, Sung, Max, Shi, \& Ong, 2012). Kessler et al. (2010) found that it is effective as a screen for DSM-IV diagnosis of serious mental illness. Both Cairney et al. (2007) and Furukawa et al. (2003) validated the K6 with Canadian general population samples.

Demographic variables collected included age, gender, year of study, years of experience with the current team, scholarship status (having or not having an athletic scholarship), starting status (being a starter or non-starter on their team), present injury status (currently injured or not), concussion history (ever been diagnosed with a concussion), time in season (pre-season, in season, playoffs, or off-season), and location of school relative to home (same town, same province or different province).

\section{Analyses}

The following predictor variables were included in the analysis: age, gender, starting status, scholarship status, injury status, concussion history, campus location relative to home, and time of season. Time of season could have four values: pre-season, in season, playoffs, or off-season. Data was analyzed using IBM SPSS, Version 23.0. Analyses included descriptive statistics for the K6 scores and a regression equation predicting K6 values from the above-mentioned variables. These variables were entered as blocks in the models because they were dummy coded (Field, 2017). Therefore, the regression equation included three blocks-age, gender, starting status, scholarship status, injury status, and 
concussion history were entered in the first block; two dummy codes for location were entered in the second block; and three dummy codes for time of season were entered in the third block. All variables were entered simultaneously within each block. Lastly, K6 scores were compared across sports via a one-way ANOVA. This ANOVA only included sports with at least 14 participants in the study (i.e., football, rugby, volleyball, hockey, basketball, soccer, swimming, and track and field).

\section{Results}

The K6 scores are summarized and sorted by demographic characteristic in Table 2. The average score in the current sample was 8.25 ( $S D=2.83$; 95\% CI [7.69-8.80]), with females $(M=9.00, S D=0.45)$ scoring higher than males $(M=7.04, S D=0.35)$. Research on the K6 has suggested that a score of 13 is an optimal cut-off for assessing the prevalence of severe mental illness in a population, where "optimal" means equalizing false positives and false negatives (Kessler et al., 2002). In the current sample, $19.8 \%$ of the student-athletes (14.7\% of males, $23.4 \%$ of females) passed this threshold.

Table 2. K6 Scores by Groups

\begin{tabular}{llc}
\hline Grouping Variable & & K6 Score $(M[S D])$ \\
\hline Gender & Male & $7.04(0.45)$ \\
Starting Status & Female & $9.00(0.35)$ \\
& Starter & $7.29(0.34)$ \\
Scholarship Status & Non-Starter & $9.48(0.45)$ \\
& Scholarship Athlete & $7.57(0.37)$ \\
Injury Status & Non-Scholarship Athlete & $8.95(0.43)$ \\
& Currently not Injured & $7.98(0.31)$ \\
Concussion Diagnosis & Currently Injured & $9.35(0.69)$ \\
& No & $8.13(0.39)$ \\
Time of Season & Yes & $8.38(0.41)$ \\
& Pre-Season & $9.79(0.69)$ \\
& In-Season & $7.92(0.40)$ \\
& Playoffs & $8.75(2.69)$ \\
Location of Residence & Same City & $8.01(0.49)$ \\
Relative to Campus & Same Province & $8.31(0.59)$ \\
& Different Province & $8.56(0.44)$ \\
\hline
\end{tabular}

Note. The $\mathrm{K} 6$ is scored on range of $\mathrm{0}-\mathbf{2 4}$, with higher scores indicating greater psychological distress.

The first regression model predicting $\mathrm{K} 6$ was significant $\left(F_{(7,276)}=5 \cdot 21, p<.001\right)$, accounting for $11.7 \%$ of the variation in K6 scores. Neither of the blocks including location or time of season significantly improved the model. The only significant predictors in the first block model were gender $(B=1.80, p<.01)$, starting status $(B=1.56, p<.05)$ and scholarships status $(B=1.18, p<.05)$. Interpretation of the unstandardized coefficient in the 
regression shows that females on average scored 1.72 points higher on the K6 (out of 24) than males, while non-starters scored on average 1.57 points higher than starters, and nonscholarship student-athletes scored 1.14 points higher than scholarship student-athletes.

The ANOVA revealed that there was a significant effect of sport on psychological distress $\left(F_{(7,244)}=2.43, p<.05\right)$ in this sample. Post hoc Bonferroni $t$-tests revealed that the only significant difference was that hockey players' K6 scores $(M=6.13, S D=4.48)$ were significantly lower than track and field participants $(M=9.51, S D=4.29)$. Subsequent analyses revealed that these sports did not differ significantly by any of the demographic variables (i.e., experience, gender).

\section{Discussion}

This large-scale study explored the prevalence of psychological distress in the Canadian university sports system. The results support the conclusion that generalized psychological distress experienced by student-athletes is quite high, with approximately $20 \%$ of the sample showing scores indicative of severe mental illness. It should be noted that the $\mathrm{K} 6$ is not a clinical diagnostic tool.

\section{Gender}

Further examination revealed that being female was associated with relatively higher levels of psychological distress. These findings agree with the majority of the literature, which has found that female athletes show higher scores of anxiety and depression when compared to male athletes (Ichraf, Ali, Khaled, Liwa, \& Ali, 2013; Junge \& FeddermanDemont, 2016; Shaal et al., 2011; Wolanin et al., 2016; Wolf, Eys, \& Kelinert, 2015). When comparing scores between genders in different forms of anxiety, Ichraf et al. (2013) reported that females scored higher on cognitive anxiety scales, while males scored higher on somatic anxiety scales. Furthermore, differences between genders can be impacted by how anxiety is viewed within a sport setting. Wolf et al. (2015) reported that males tend to interpret pre-competition anxiety as more facilitative compared to females. It should be noted that the imbalance in willingness to report any psychological distress symptoms is a common issue when comparing psychological distress levels between genders. Shaal et al. (2011) expressed that the higher level of willingness in females compared to males to report symptoms related to anxiety could play a substantial role in the differences often detected between genders.

\section{Starting Status}

Athletes who self-reported as "starters" experienced significantly less psychological distress compared to those who did not. Although the factor of starting status has not generated the type of research within sport psychology that gender has, there are some interesting results with respect to state anxiety that are consistent with this finding. For example, it has been repeatedly found that starters report significantly lower levels of precompetitive state anxiety than non-starting athletes (Han et al., 2011; Woods, 2007; Wolf et al., 2015), and that starters view state anxiety as more facilitative than non-starters (Wolf et al., 2015). Furthermore, when comparing high- and low-ranked athletes, Han et al. (2011) found that high-ranked players had lower competitive anxiety and reacted to errors with less anxiety than lower-ranked players. 


\section{Scholarship Status}

In the current sample, athletes with scholarships had significantly lower K6 scores than those without scholarships. Although there is very little research on scholarship status and mental health of student-athletes, the current results are inconsistent with research that has found that maintaining a scholarship can be a significant cause of stress and burnout in student-athletes (Almódovar, 2017; Rodriguez, 2014), particularly for females (Judge, Bell, Theodore, Simon, \& Bellar, 2012). It should be noted that those results are based on American data, and as stated above the American and Canadian intercollegiate sport systems are substantially different, particularly with respect to revenue generation.

\section{Sport Type}

There was a significant effect of sport type on psychological distress, whereby track and field athletes reported significantly higher psychological distress than hockey players. This is consistent with the findings of Wolanin et al. (2016), who found that female track and field athletes had the highest prevalence of depressive symptoms of all the athletes in their study. These results suggest that there may be something specific to the context of collegiate track and field that requires further investigation.

\section{Non-Influential Factors}

Interestingly, some factors previously found to share a relationship with psychological distress in university students were not influential in the current sample of student-athletes. These include year of study and distance from home. It may be that student-athletes are more accustomed to travel and being away from home due to their athletic competitions, making their time away at university less stressful. Perhaps the most interesting nonsignificant finding was the lack of effect of injuries and concussions on psychological distress. However, this may be due to a specific characteristic of the sample or data collection method. Specifically, the operational definition of concussion history used in the analysis was whether the student-athlete had ever been diagnosed with a concussion. Although we did ask if respondents currently were diagnosed with a concussion, the number of responses was too small to support any analysis $(n=3)$. Unfortunately, we can make no conclusive statement regarding concussions and mental health with university student-athletes.

This study did not include a comparison group of student non-athletes. However, given the prevalence of normative data on the $\mathrm{K} 6$ and other generalized scales of psychological distress, it is possible to imply the relative status of mental health of university studentathletes in Canada. For instance, Wade and Cairney (1997) found K6 scores for the general population of Canada to be approximately 4.0 for males and 4.5 for females, whereas the levels in the current sample were 7.06 and 9.00, respectively. Furthermore, in the current study, $20 \%$ of varsity athletes reported levels of anxiety and depression indicative of severe mental illness. Comparatively, the American College Health Association's (2016) Canadian Survey found that 9.3\% of Canadian post-secondary students (96.1\% of whom were not student-athletes) felt "so depressed it was difficult to function," and 13.9\% felt "overwhelming anxiety" in the past 30 days. After contextualizing the current findings within this literature, it appears that the levels of psychological distress experienced by student-athletes in Canada are substantially higher than student non-athletes and the general public in the same age cohort. 


\section{Limitations}

As with any study using self-reported questionnaires, this study has the potential of self-report bias affecting the participants' responses. Along those same lines, mental health issues are not an easy topic to be honest and frank about, even via an anonymous survey. Therefore, it is possible that the rates reported in this article may be somewhat inaccurate. Sample size is also a limitation that must be discussed; the current study had a sample size of 284 , which may not be large enough to truly represent the entire population of Canadian student-athletes. Most importantly, with a lower sample size it is possible that the current sample was comprised of individuals whose experiences and/or attitudes relative to mental health resulted in responses that were not indicative of the population as a whole. These limitations notwithstanding, the research to date, including the current study, suggests that mental health issues in Canadian intercollegiate sport are a significant matter, and more research is clearly needed to fully understand the issue.

\section{Conclusion}

The current study revealed that the mental health of student-athletes in Canada could be a significant issue. These individuals report levels of psychological distress that appear to be significantly higher than both their non-athlete counterparts and society in general. While there are several factors that are indicative of relatively greater levels of distress, it should be noted that this appears to be a general issue in that it is relatively constant across issues like year of study and time of season. Although females, non-starters, and non-scholarship students may experience particularly high levels of anxiety and depression, Canadian student-athletes as a population display a dangerous prevalence of psychological distress.

Future research should focus on developing a more complete understanding of this issue. Specifically, longitudinal studies focusing on how psychological distress may change during the transition from high school to university, or over the course of the academic year and sport season, would be very valuable. Also, research with a clinical tool may be informative; even though the current results were based on a screening tool, the mental health of this population is definitely an issue for future applied interventions and programs. Specifically, applications designed to reduce psychological distress in studentathletes and increase awareness of mental health issues in coaching and support staff are certainly warranted.

\section{References}

Adlaf, E. M., Gliksman, L., Demers, A., \& Newton-Taylor, B. (2001). The prevalence of elevated psychological distress among Canadian undergraduates: Findings from the 1998 Canadian Campus Survey. Journal of American College Health, 5o(2), 67-72. https:// doi.org/10.1080/07448480109596009

Almodóvar, A. A. (2017). Examining burnout in Division I collegiate athletes: Identifying the major factors and level of importance in an athlete's life. Siegel Institute Ethics Research Scholars, 2, 1-33. Retrieved from http://digitalcommons.kennesaw. edu/siers/vol2/iss1/1 
American College Health Association. (2016, Spring). National College Health Assessment II: Ontario Canada reference group, executive summary. Retrieved from http://oucha.ca/pdf/2016_NCHA-II_WEB_SPRING_2016_ONTARIO_CANADA_ REFERENCE_GROUP_EXECUTIVE_SUMMARY.pdf

Cairney, J., Veldhuizen, S., Wade, T. J., Kurdyak, P., \& Streiner, D. L. (2007). Evaluation of 2 measures of psychological distress as screeners for depression in the general population. The Canadian Journal of Psychiatry, 52(2), 111-120. https://doi. org/10.1177/070674370705200209

Davoren, A., \& Hwang, S. (2014). Mind, body and sport: Depression and anxiety prevalence in student-athletes. Indianapolis, IN: Nation Collegiate Athletics Association. Retrieved from https://www.naspa.org/images/uploads/events/Mind_Body_and_Sport. pdf

Eisenberg, D., Golberstein, E., \& Gollust, S. E. (2007). Help-seeing and access to mental health care in a university student population. Medical Care, 45(7), 594-601. https://doi.org/10.1097/MLR.obo13e31803bb4c1

Field, A. (2017). Discovering statistics using IBM SPSS (5th ed.). Thousand Oaks, CA: Sage.

Furukawa, T. A., Kessler, R. C., Slade, T., \& Andrews, G. (2003). The performance of the K6 and K10 screening scales for psychological distress in the Australian National Survey of Mental Health and Well-Being. Psychological Medicine, 33(2), 357-362. https://doi. org/10.1017/Soo33291702006700

Han, D. H., Park, H. W., Kee, B. S., Na, C., Na, D. H. E., \& Zaichkowsky, L. (2011). Performance enhancement with low stress and anxiety modulated by cognitive flexibility. Korean Neuropsychiatric Association, 8(3), 221-226. https://doi.org/10.4306/ pi.2011.8.3.221

Hunt, J., \& Eisenberg, D. (2010). Mental health problems and help-seeking behavior among college students. Journal of Adolescent Health, 46(1), 3-10. https://doi. org/10.1016/j.jadohealth.2009.08.008

Ichraf, A., Ali, B. M., Khaled, T., Liwa, M., \& Ali, R. (2013). Effect of gender and type of sport on anxiety and self-esteem. International Journal of Humanities and Social Science Invention, 2(3), 55-61. Retrieved from http://www.ijhssi.org/papers/v2(3)/ version-2/J235561.pdf

Judge, L. W., Bell, R. J., Theodore, R., Simon, L., \& Bellar, D. (2012). An exploratory examination of burnout in NCAA division II athletes. Journal of Intercollegiate Sport, 5(2), 230-240. https://doi.org/10.1123/jis.5.2.230

Junge A., \& Fedderman-Demont, N. (2016). Prevalence of depression and anxiety in top-level male and female football players. BMJ Open: Sport \& Exercise Medicine, 2(1). https://doi.org/10.1136/bmjsem-2015-000087

Kessler, R. C., Andrews, G., Colpe, L. J., Hiripi, E., Mroczek, D. D., Normand, S. L., ... Zaslavsky, A. M. (2002). Short screening scales to monitor population prevalence and trends in non-specific psychological distress. Psychological Medicine, 32(6), 959-976. https://doi.org/10.1017/So033291702006074 
Kessler, R. C., Green, J. G., Gruber, M. J., Sampson, N. A., Bromet, E., Cuitan, M., ... Zaslavsky, A. M. (2010). Screening for serious mental health illness in the general population with the K6 screening scale: Results from the WHO World Mental Health (WMH) Survey initiative. International Journal of Methods in Psychiatric Research, 19 (S1), 4-22. https://doi.org/10.1002/mpr.310

Kimball, A., \& Freysinger, V. (2003). Leisure, stress and coping: The sport participation of collegiate students-athletes. Leisure Sciences, 25(2-3), 115-141. https:// doi.org/10.1080/01490400306569

Lopez, R. L., \& Levy, J. J. (2013). Student-athletes' perceived barriers to and preferences for seeking counseling. Journal of College Counseling, 16(1), 19-31. https:// doi.org/10.1002/j.2161-1882.2013.00024.x

Miller, K. E., \& Hoffman, J.M. (2009). Mental well-being and sport-related identities in college students. Sociology of Sport Journal, 26(2), 335-356. https://doi.org/10.1123/ ssj.26.2.335

Miller, P.S., \& Kerr, G. (2002). The athletic, academic and social experiences of intercollegiate student-athletes. Journal of Sport Behavior, 25(4), 346-367.

Mori, S. C. (2000). Addressing the mental health concerns of international students. Journal of Counseling \& Development, 78(2), 137-144. https://doi. org/10.1002/j.1556-6676.2000.tbo2571.x

Moulton, M. A., Molstad, S., \& Turner, A. (1997). The role of athletic trainers in counseling collegiate athletes. Journal of Athletic Training, 32(2), 148-150. Retrieved from https://europepmc.org/backend/ptpmcrender.fcgi?accid=PMC1319818\&blobtype $=\mathrm{pdf}$

National Collegiate Athletic Association. (n.d.). Scholarships. Retrieved May 21, 2008, from http://www.ncaa.org/student-athletes/future/scholarships.

Ontario College Health Association. (2009, December). Towards a comprehensive mental health strategy: The crucial role of colleges and universities as partners. Retrieved from http://oucha.ca/pdf/mental_health/2009_12_OUCHA_Mental_Health_Report. pdf

Ontario University Athletics. (n.d.). Student financial awards. Retrieved May 21, 2008, from http://www.oua.ca/student_athletes/student_financial_awards

Prochaska, J. J., Sung, H. Y., Max, W., Shi, Y., \& Ong, M. (2012). Validity study of the K6 scale as a measure of moderate mental distress based on mental health treatment need and utilization. International Journal of Methods in Psychiatric Research, 21(2), 88-97. https://doi.org/10.1002/mpr.1349

Rodriguez, A. (2014). International student-athletes and stress: Implications for American universities' administrators. Journal of Academic Administration in Higher Education, 1O(2), 39-47. Retrieved from https://files.eric.ed.gov/fulltext/EJ1140940.pdf

Shaal, K., Tafflet, M., Nassif, H., Thibault, V., Picahrd, C., Alcotte, M., ...Toussaint, J. F. (2011). Psychological balance in high level athletes: Gender-based differences and sport-specific patterns. PLoSONE, 6(5), e19007. https://doi.org/10.1371/journal. pone.0019007 
Stallman, H. M. (2010). Psychological distress in university students: A comparison with general population data. Australian Psychologist, 45(4), 249-257. https://doi.org /10.1080/00050067.2010.482109

USports. (2017, September). Welcome to the new and improved USPORTS.ca. Retrieved from https://usports.ca/en/news/2017/o9/3679716956/the-new-andimproved-usports-ca

World Health Organization. (n.d.). Gender and women's mental health: Gender disparities and mental health, the facts. Retrieved February 20, 2019 from http://www. who.int/mental_health/prevention/genderwomen/en/

Wade,T.J.,\&Cairney,J.(1997).Ageand depressioninanationally representativesample of Canadians: A preliminary look at the National Population Health Survey. Canadian Journal of Public Health, 88 (5), 297-302. Retrieved from http://journal.cpha.ca/index. $\mathrm{php} / \mathrm{cjph} /$ article/view/999

Wolanin, A., Hong, E., Marks, D., Panchoo, K., \& Gross, M. (2016). Prevalence of clinically elevated depressive symptoms in college athletes and differences by gender and sport. British Journal of Sports Medicine, 5o(3), 167-171. https://doi.org/10.1136/ bjsports-2015-095756

Wolf, S. A., Eys, M. A., \& Kelinert, J. (2015). Predictors of the precompetitive anxiety response: Relative impact and prospects for anxiety regulation. International Journal of Sport and Exercise Psychology, 13(4), 344-358. https://doi.org/10.1080/161219 7X.2014.982676

Woods, B. (2007). An exploration of substitutes' experiences in football (Doctoral dissertation). Retrieved from EThOS e-theses online service. (EthOS ID: uk.bl. ethos.489490)

\section{Contact Information}

Philip Sullivan

Department of Kinesiology

Brock University

phil.sullivan@brocku.ca

Philip Sullivan is a professor in the Department of Kinesiology at Brock University. He has degrees in psychology from Memorial University of Newfoundland and in human kinetics from the University of Windsor, and a PhD from Michigan State University. He researches social dynamics within sport, with a focus on the mental health and mental health literacy of student-athletes. He is also a varsity coach at Brock University.

Mishka Blacker is from Toronto, Ontario. She has an undergraduate degree in psychology from Ryerson University, and completed her master's degree in applied health science at Brock University. She is currently pursuing her PhD at Brock University with a focus on the mental health of athletes in relation to well-being and performance. 
Jessica Murphy is a second-year PhD student in applied health sciences at Brock University. She received her undergraduate degree in kinesiology from Brock University, and her MSc from the University of Saskatchewan, focusing on athlete maturation and performance. Jessica's research now centres around the mental health of athletes, including help-seeking intentions and the potential effects of interventions. 